\section{Cosci ech}

p-ISSN: 2723-567X

e-ISSN: 2723-5661
Jurnal Computer Science and Information Technology

(CoSciTech)

http://ejurnal.umri.ac.id/index.php/coscitech/index

\title{
Sistem Informasi Geografis Pemetaan Tempat Pembungan Sampah Sementara di Kota Pekanbaru Dengan Mencari Rute Terdekat Menggunakan Algoritma A Star (A*)
}

\author{
Maruba Hutabalian' ${ }^{1}$, Sunanto ${ }^{2}$, Januar Al Amien ${ }^{3}$ \\ email: ${ }^{1}$ maruba@student.ac.id, ${ }^{2}$ sunanto@umri.ac.id, ${ }^{2}$ januaralamien@umri.ac.id \\ ${ }^{123}$ Teknik Informatika, Fakultas Ilmu Komputer, Universitas Muhammadiyah Riau \\ Diterima: 06 Oktober 2020 | Direvisi: - | Disetujui: 11 Desember 2021 \\ (C2021 Program Studi Teknik Informatika Fakultas Ilmu Komputer, \\ Universitas Muhammadiyah Riau, Indonesia
}

\begin{abstract}
Abstrak
Permasalahan sampah yang mendasar adalah masih banyaknya masyarakat yang membuang sampah tidak pada tempat dan waktunya sehingga beberapa titik lokasi sampah belum di-monitoring dan belum diketahui lokasinya. Tujuan penelitian ini adalah merancang dan membangun sebuah sistem informasi geografis pemetaan Tempat Penampungan Sampah Sementara (TPSS) dengan mencari rute terdekat titik lokasi-lokasi sampah yang berada di sekitaran mereka, sehingga masyarakat mengetahui tempat pembuangan sementara yang resmi dari Dinas Lingkungan Hidup dan Kebersihan Kota Pekanbaru. Dalam pengembangan sistem menggunakan Algoritma A- star, karena Algoritma A* (A Star) merupakan salah satu algoritma pencarian rute yang optimal dan komplit. Optimal berarti rute yang dihasilkan adalah rute yang paling baik dan komplit. Hasil dari penelitian ini adalah membuat sistem informasi geografis pemetaan tempat pembuangan sampah di Kota Pekanbaru menggunakan algoritma A-Star dengan mencari rute terdekat yang tersebar di kota pekanbaru. Sistem ini diharapkan dapat bermanfaat bagi masyarakat dan instansi terkait untuk dapat saling bekerja sama dan berinteraksi dengan teknologi untuk mengatasi permasalahan sampah dengan lebih baik.
\end{abstract}

Kata kunci: Pemetaan, Rute, Sampah, Sistem Informasi Geografis, algoritma A star

\section{Geographic Information System Mapping Temporary Waste Disposal Sites in Pekanbaru City by Finding the Nearest Route Using the A Star (A*) Algorithm}

\begin{abstract}
Garbage is the residue of human daily activities or natural processes in solid form. The basic waste problem is that there are still many people who dispose of their garbage in inappropriate places and times, so that some points of garbage locations have not been monitored and their locations are not known. The purpose of this study is to design and build a geographic information system for mapping Temporary Waste Shelters (TPSS) by finding the closest route to the point of waste locations around them, so that the public knows the official temporary disposal sites from the Pekanbaru City Environmental and Hygiene Service. The system development uses the A-star Algorithm, because the A* (A Star) Algorithm is one of the optimal and complete route search algorithms. Optimal means that the resulting route is the best and most complete route. The result of this research is to create a geographic information system for mapping garbage dumps in Pekanbaru City using the A-Star algorithm by looking for the closest route that is spread out in the city of Pekanbaru. This system is expected to be useful for the community and related agencies to be able to work together and interact with technology to better solve the waste problem.
\end{abstract}

Keywords: Mapping, Routes, Rubbish, Geographic Information Systems, Algorithm A star

\section{Pendahuluan}

Semakin bertambahnya penduduk dan kurangnya kesadaran masyarakat dalam menjaga lingkungan sekitar akan menjadi persoalan dalam menangani sampah yang terdapat di masyarakat terlebih di kota pekanbaru. Permasalahan ini akan menjadi sangat serius karena dampak yang ditimbulkan, karena sampah dapat mempengaruhi kehidupan masyarakat secara luas. Misalnya, penumpukan sampah dipingir- pinggir jalan, bau yang kurang sedap, dan banjir akibat terganggunya aliran sungai

doi: https://doi.org/10.37859/coscitech.v2i2.2936 
oleh sampah yang dibuang sembarangan. Untuk itu, di butuhkan kesadaran seluruh masyarakat untuk membuang sampah pada tempatnya.

Salah satu cara yang efektif untuk mengelola sampah adalah dengan membuatkan lokasi Tempat Pembuangan Sampah Sementara (TPSS). Hal ini diharapkan agar dapat mengurangi volume sampah yang ada di Tempat Pembuangan Akhir Sampah dan timbunan sampah yang ada di badan jalan maupun lahan kosong yang dijadikan pembuangan sampah oleh masyarakat.

Salah satu cara untuk memberikan informasi lokasi TPSS yaitu dengan membuatkan sistem informasi geografis pemetaan tempat pembungan sampah sementara di Kota Pekanbaru dengan mencari rute terdekat Menggunakan Algoritma A Star (a*)" untuk memudahkan masyarakat mengetahui titik lokasi terdekat tempat pembuangan sampah di sekitar mereka. Dengan adanya Sistem informasi geografis pemetaan titik lokasi tempat pembungan sampah sementara, di harapakan masyarakat tidak lagi membuang sampah sembarangan karena telah mengetahui titik lokasi tempat pembungan sampah yang di sediakan oleh Dinas Lingkungan Hidup dan Kebersihan Kota Pekanbaru.

\section{Metode Penelitian}

\subsection{Pengertian sampah}

Menurut (Elmayati, Cindi Wulandari, dan Hendra Saputra. 2018), sampah adalah sesuatu yang tidak dipergunakan lagi, yang tidak dapat dipakai lagi, yang tidak disenangi dan harus dibuang. maka sampah tentu saja harus dikelola dengan sebaik- baiknya, sedemikian rupa sehingga hal-hal yang negatif bagi kehidupan tidak sampai terjadi.

Menurut (Kurniawan, Octadear Reza, Meyka Nurul Anggraini dan Pradityo Utomo. 2019), mendefinisikan sampah adalah Sampah adalah barang yang dianggap sudah tidak terpakai dan dibuang oleh pemilik/pemakai sebelumnya, tetapi bagi sebagian orang masih bisa dipakai jika dikelola dengan prosedur yang benar.

\subsection{Sistem Informasi Geografis (SIG)}

Sistem Informasi Geografis adalah suatu komponen yang terdiri dari perangkat keras, perangkat lunak, data geografis dan sumberdaya manusia yang bekerja sama secara efektif untuk menangkap, menyimpan, memperbaiki, memperbaharui, mengelola, memanipulasi, mengintegrasikan data dalam suatu informasi berbasis geografis.

\subsection{Web Geographic Information System}

Web GIS adalah suatu sistem yang dapat terhubung kedalam jaringan internet yang digunakan untuk mengumpulkan, menyimpan, dan menampilkan data informasi bergeoreferensi atau data yang mengidentifikasikan lokasi objek tanpa adanya kebutuhan penggunaan software SIG.

\subsection{Bahasa Pemograman dan Database}

Bahasa pemograman dan database menjelaskan tentang bahasa pemograman apa saja yang digunakan beserta penggunaan database.

\subsubsection{Hypertext Pre Processor (PHP)}

PHP adalah bahasa scripting dengan tujuan umum open source yang digunakan dan sangat sesuai untuk pengembangan web dan dapat disematkan ke dalam HyperText Markup Language (HTML).

\subsubsection{Codeigniter}

CodeIgniter adalah sebuah web application network yang bersifat open source yang digunakan untuk membangun aplikasi php dinamis. CodeIgniter menjadi sebuah framework PHP dengan model MVC (Model, View, Controller) untuk membangun website dinamis dengan menggunakan PHP yang dapat mempercepat pengembang untuk membuat sebuah aplikasi.

\subsubsection{MySQL}

MySQL adalah database open source terpopuler di dunia dengan kinerja, keandalan dan kemudahan penggunaan yang terbukti, MySQL telah menjadi pilihan database terdepan untuk aplikasi berbasis web, yang digunakan.

\subsubsection{Xampp}

Xampp merupakan tools yang menyediakan paket perangkat lunak ke dalam satu buah paket. Saat melakukan instalasi Xampp maka tidak perlu lagi melakukan instalasi dan konfigurasi web server Apache, PHP dan MySQL secara manual.

\subsubsection{Google Maps API}

API merupakan singkatan dari Application programing interface yaitu yang berfungsi sebagai alat bantu pemrograman yang disediakan oleh aplikasi atau layanan tertentu supaya bisa di integrasikan dengan aplikasi yang telah di buat.

\subsubsection{Sublime Text}

Sublime text merupakan sebuah aplikasi editor yang dapat berjalan diberbagai platform Operating system dengan menggunakan teknologi Pyhton API. Aplikasi inni sangat banyak digunakan oleh para programer untuk menuliskan kode nya, karena tampilan nya yang sangat simpel dan menarik.

\subsubsection{Unidied Modelling Language (UML)}

Unified Modelling Language (UML) adalah bahasa grafis untuk mendokumentasi, menspesifikasikan dan membangun sistem perangkat lunak. UML berorientasi objek, menerapkan banyak level abstraksi, tidak bergantung proses pengembangan, tidak bergantung bahasa dan teknologi, pemaduan beberapa notasi diberagam metodologi adalah usaha bersama dari banyak pihak dan didukung oleh sistem-sistem yang 20 diintegrasikan lewat Extensible Markup Languange (XML)

\subsection{Algoritma A STAR (A*)}

Algoritma $A^{*}$ merupakan salah satu jenis algoritma yang digunakan untuk menyelesaikan kasus yang berhubungan dengan path finding (pencarian jalan). Dalam hasil pencariannya A* dikatakan complete dan optimal. Algoritma A* menggunakan cara pencarian secara Breatdth First Search, dimana pencarian dilakukan dengan cara melebar ke setiap node pada level yang sama, dan nantinya akan menemukan rute terbaik dari titik awal sampai tujuan. Algoritma A* juga dilengkapi dengan suatu 
fungsi heuristik. Fungsi heuristik yang terdapat pada algoritma A* digunakan sebagai optimasi dalam menentukan node tujuan yang akan dipilih.

Algortima $A^{*}$ merupakan algoritma breatdth-first search yang menggunakan fungsi heuristik yang kompleks untuk memilih path. Algoritma breatdth-first search selalu memperluas jalan untuk menuju node yang akan dilewati, tetapi tidak memperhitungkan cost ke simpul tersebut.

Algoritma ini memeriksa node dengan menggabungkan $\mathrm{g}(\mathrm{n})$, yaitu cost yang dibutuhkan untuk mencapai sebuah node dan $\mathrm{h}(\mathrm{n})$ yaitu cost yang didapat dari node ke tujuan. Sehingga dapat di rumuskan sebagai:

$$
\text { Rumus }: \boldsymbol{f}(\boldsymbol{n})=\boldsymbol{g}(\boldsymbol{n})+\boldsymbol{h}(\boldsymbol{n})
$$

Keterangan :

f(n): adalah estimasi total biaya (cost) sebuah jalur (path) dari node awal ke node tujuan (goal) melalui node n.

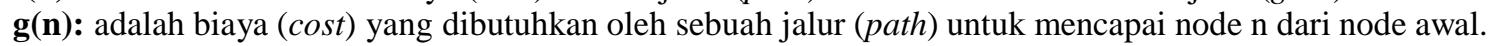

$\mathbf{h}(\mathbf{n})$ : adalah estimasi biaya (cost) sebuah jalur (path).

Ada Ada beberapa penghitungan jarak yang sering digunakan dalam algoritma A*, Yaitu:

1. Jarak Manhattan

Fungsi ini merupakan fungsi heuristik yang paling umum digunakan. Fungsi ini hanya akan menjumlahkan selisih nilai x dan y dari dua buah titik. Fungsi ini dinamakan Manhattan karena di kota Manhattan, Amerika, jarak dari dua lokasi umumnya dihitung dari blok-blok yang harus dilalui saja dan tentunya tidak bisa dilalui secara diagonal. Perhitungannya dapat ditulis sebagai berikut:

$$
\mathrm{h}(\mathrm{n})=\operatorname{abs}(-)+\operatorname{abs}(-)
$$

Dimana $\mathrm{h}(\mathrm{n})$ merupakan perkiraan cost dari node $\mathrm{n}$ ke node tujuan yang dihitung dengan fungsi heuristik. Variable merupakan koordinat $\mathrm{x}$ dari node asal, sedangkan variabel merupakan koordinat y dari node asal. Variabel merupakan koordinat $\mathrm{x}$ dari node tujuan dan merupakan koordinat y dari node tujuan. Nilai dari h(n) akan selalu bernilai positif.

2. Jarak Euclid

Heuristik ini akan menghitung jarak berdasarkan panjang garis yang dapat ditarik dari dua buah titik. Perhitungannya dapat dituliskan sebagai berikut :

$$
h(n)=\left(x_{1} \sqrt{\left.-x_{2}\right)^{2}+\left(y_{1}-y_{2}\right)^{2}}\right.
$$

Dalam kasus ini, skala relatif nilai g mungkin akan tidak sesuai lagi dengan nilai fungsi heuristik h. Karena jarak euclidian selalu lebih pendek dari jarak manhattan, maka dapat dipastikan selalu akan didapatkan jalur terpendek, walaupun secara komputansi lebih berat.

\section{Jarak Euclidian Kuadrat}

Dalam beberapa literatur juga disebutkan jika nilai g adalah 0 , maka lebih baik jika ongkos komputansi operasi pengakaran pada heuristik jarak Euclidian dihilangkan saja, menghasilkan rumus sebagai berikut:

$$
\mathrm{h}(\mathrm{n})=\sqrt{\left(\mathrm{x}_{1}-\mathrm{x}_{2}\right)^{2}+\left(\mathrm{y}_{1}-\mathrm{y}_{2}\right)^{2}}
$$

Fungsi heuristik sangat berpengaruh terhadap kelakuan algoritma $A^{*}$, yaitu:

1. Apabila $h(n)$ selalu bernilai 0, maka hanya $g(n)$ yang akan berperan, dan $A^{*}$ berubah menjadi Algoritma Dijkstra, yang menjamin selalu akan menemukan jalur terpendek.

2. Apabila $\mathrm{h}(\mathrm{n})$ selalu lebih rendah atau sama dengan ongkos perpindahan dari titik $\mathrm{n}$ ke tujuan, maka $\mathrm{A}^{*}$ dijamin akan selalu menemukan jalur terpendek. Semakin rendah nilai h(n), semakin banyak titik-titik yang diperiksa A*, membuatnya semakin lambat.

3. Apabila $\mathrm{h}(\mathrm{n})$ tepat sama dengan ongkos perpindahan dari $\mathrm{n}$ ke tujuan, maka $\mathrm{A}^{*}$ hanya akan mengikuti jalur terbaik dan tidak pernah memeriksa satupun titik lainnya, membuatnya sangat cepat. Walaupun hal ini belum tentu bisa diaplikasikan ke semua kasus, ada beberapa kasus khusus yang dapat menggunakannya.

4. Apabila $\mathrm{h}(\mathrm{n})$ kadangkala lebih besar dari ongkos perpindahan dari $\mathrm{n}$ ke tujuan, maka $\mathrm{A}^{*}$ tidak menjamin ditemukannya jalur terpendek, tapi prosesnya cepat.

\subsection{Proses Hasil Pencarian Rute Terdekat Dengan Algoritma A*}

Pencarian rute terdekat pertama kali harus menghitung biaya estimasi atau perkiraan antara dua titik dengan menggunakan fungsi heuristik. Fungsi heuristik yang digunakan adalah Manhattan. Fungsi heuristik yang paling umum digunakan, Fungsi ini hanya akan menjumlahkan selisih nilai $\mathrm{x}$ dan y dari dua buah titik.

Contoh kasus pada perhitungan ini yaitu mencari jalur terdekat dari titik asal, Dengan menggunakan sistem informasi geografis yang telah dibuat. Titik asal berada di kampus Universitas Muhammadiyah Riau di jl.tuanku tambusai di kota pekanbaru dengan memilih tujuan Tps Pasar Bawah menggunakan sistem yang telah di buat. 
Untuk menghitung perkiraan antara titik awal ke titik tujuan dengan menggunakan fungsi hauristik. sebagai contoh kasus pada perhitungan ini yaitu mencari jalur terdekat, yang di gambarkan kedalam bentuk huruf. Huruf (A) adalah sebagai titik Universitas Muhammadiyah Riau Jl.Tuanku tambusai merupakan titik awal, sedangkan huruf (J) adalah titik Tps Pasar Bawah Wisata sebagai titik tujuan. Sedangan titik Huruf lain nya adalah sebagai persimpangan dalam menuju titik tujuan. skema jalur dan persimpangan titik tujuan di gambarkan seperti jalur yang terdapat pada google maps Seperti gambar di bawah

Ada Ada beberapa penghitungan jarak yang sering digunakan dalam algoritma ${ }^{*}$, Yaitu:

1. Jarak Manhattan

Fungsi ini merupakan fungsi heuristik yang paling umum digunakan. Fungsi ini hanya akan menjumlahkan selisih nilai x dan y dari dua buah titik. Fungsi ini dinamakan Manhattan karena di kota Manhattan, Amerika, jarak dari dua lokasi umumnya dihitung dari blok-blok yang harus dilalui saja dan tentunya tidak bisa dilalui secara diagonal. Perhitungannya dapat ditulis sebagai berikut:

$$
\mathrm{h}(\mathrm{n})=\operatorname{abs}(-)+\operatorname{abs}(-)
$$

Dimana $\mathrm{h}(\mathrm{n})$ merupakan perkiraan cost dari node $\mathrm{n}$ ke node tujuan yang dihitung dengan fungsi heuristik. Variable merupakan koordinat $\mathrm{x}$ dari node asal, sedangkan variabel merupakan koordinat y dari node asal. Variabel merupakan koordinat x dari node tujuan dan merupakan koordinat y dari node tujuan. Nilai dari h(n) akan selalu bernilai positif.

2. Jarak Euclid

Heuristik ini akan menghitung jarak berdasarkan panjang garis yang dapat ditarik dari dua buah titik. Perhitungannya dapat dituliskan sebagai berikut :

$$
h(n)=\quad\left(x_{1} \sqrt{\left.-x_{2}\right)^{2}+\left(y_{1}-y_{2}\right)^{2}}\right.
$$

Dalam kasus ini, skala relatif nilai g mungkin akan tidak sesuai lagi dengan nilai fungsi heuristik h. Karena jarak euclidian selalu lebih pendek dari jarak manhattan, maka dapat dipastikan selalu akan didapatkan jalur terpendek, walaupun secara komputansi lebih berat.

\section{Jarak Euclidian Kuadrat}

Dalam beberapa literatur juga disebutkan jika nilai g adalah 0 , maka lebih baik jika ongkos komputansi operasi pengakaran pada heuristik jarak Euclidian dihilangkan saja, menghasilkan rumus sebagai berikut:

$$
h(n)=\sqrt{\left(x_{1}-x_{2}\right)^{2}+\left(y_{1}-y_{2}\right)^{2}}
$$

Fungsi heuristik sangat berpengaruh terhadap kelakuan algoritma $A^{*}$, yaitu:

1. Apabila $\mathrm{h}(\mathrm{n})$ selalu bernilai 0, maka hanya $\mathrm{g}(\mathrm{n})$ yang akan berperan, dan A* berubah menjadi Algoritma Dijkstra, yang menjamin selalu akan menemukan jalur terpendek.

2. Apabila $\mathrm{h}(\mathrm{n})$ selalu lebih rendah atau sama dengan ongkos perpindahan dari titik $\mathrm{n}$ ke tujuan, maka $\mathrm{A}^{*}$ dijamin akan selalu menemukan jalur terpendek. Semakin rendah nilai $h(n)$, semakin banyak titik-titik yang diperiksa $A^{*}$, membuatnya semakin lambat.

3. Apabila $h(n)$ tepat sama dengan ongkos perpindahan dari $n$ ke tujuan, maka $A^{*}$ hanya akan mengikuti jalur terbaik dan tidak pernah memeriksa satupun titik lainnya, membuatnya sangat cepat. Walaupun hal ini belum tentu bisa diaplikasikan ke semua kasus, ada beberapa kasus khusus yang dapat menggunakannya.

4. Apabila $h(n)$ kadangkala lebih besar dari ongkos perpindahan dari $n$ ke tujuan, maka $A^{*}$ tidak menjamin ditemukannya jalur terpendek, tapi prosesnya cepat.

\subsection{Proses Hasil Pencarian Rute Terdekat Dengan Algoritma A*}

Pencarian rute terdekat pertama kali harus menghitung biaya estimasi atau perkiraan antara dua titik dengan menggunakan fungsi heuristik. Fungsi heuristik yang digunakan adalah Manhattan. Fungsi heuristik yang paling umum digunakan, Fungsi ini hanya akan menjumlahkan selisih nilai $\mathrm{x}$ dan y dari dua buah titik.

Contoh kasus pada perhitungan ini yaitu mencari jalur terdekat dari titik asal, Dengan menggunakan sistem informasi geografis yang telah dibuat. Titik asal berada di kampus Universitas Muhammadiyah Riau di jl.tuanku tambusai di kota pekanbaru dengan memilih tujuan Tps Pasar Bawah menggunakan sistem yang telah di buat.

Untuk menghitung perkiraan antara titik awal ke titik tujuan dengan menggunakan fungsi hauristik. sebagai contoh kasus pada perhitungan ini yaitu mencari jalur terdekat, yang di gambarkan kedalam bentuk huruf. Huruf (A) adalah sebagai titik Universitas Muhammadiyah Riau Jl.Tuanku tambusai merupakan titik awal, sedangkan huruf (J) adalah titik Tps Pasar Bawah Wisata sebagai titik tujuan. Sedangan titik Huruf lain nya adalah sebagai persimpangan dalam menuju titik tujuan. skema jalur dan persimpangan titik tujuan di gambarkan seperti jalur yang terdapat pada google maps Seperti gambar di bawah ini: 


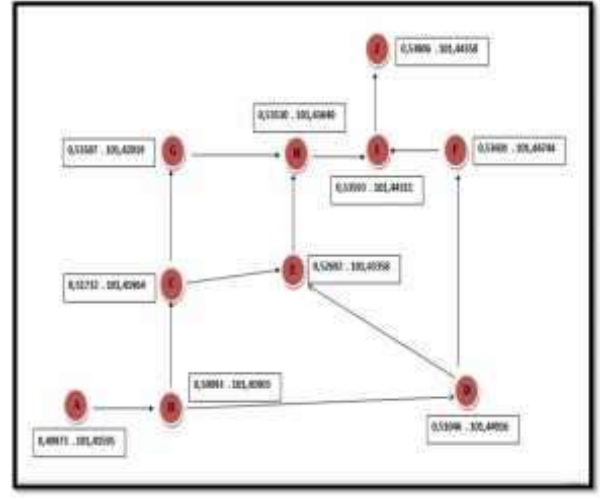

Gambar 1. Graf Pencarian Rute Terdekat

Tabel 1. Keterangan Daftar koordinat masing-masing

\begin{tabular}{|l|c|c|}
\hline No & Note & Koordinat \\
\hline 1. & A & $0,49973.101,41595$ \\
\hline 2. & B & $0,50093.101,41903$ \\
\hline 3. & C & $0,51732.101,41964$ \\
\hline 4. & D & $0,51046.101,44916$ \\
\hline 5. & E & $0,52692.101,43358$ \\
\hline 6. & F & $0,53601.101,44744$ \\
\hline 7. & G & $0,53507.101,42019$ \\
\hline 8. & H & $0,53530.101,43649$ \\
\hline 9. & I & $0,53593.101,44311$ \\
\hline 10. & J & $0,53806.101,44358$ \\
\hline
\end{tabular}

Untuk mencapai ke tujuan, terlebih dahulu menghitung nilai h(n) atau nilai perkiraan dengan fungsi heuristik. Dimana nilai titik tersebut diambil berdasarkan nilai koordinat. Berikut perhitungan antara titik koordinat dengan menggunakan rumus Manhattan Distance. Hasil Heuristik yang di peroleh adalah sebagai berikut

A. Heuristik A $(0,49973$. 101,41595) $\rightarrow$ B $(0,50093$. 101,41903)

$\mathrm{H}(\mathrm{a}, \mathrm{b})=(0,50093-0,49973)+(101,41903-101,41595)$

$\mathrm{H}(\mathrm{a}, \mathrm{b})=(0,0012+0,00308) \quad=0,00428$

Hasil di ubah dalam derajat. $\quad=0,24$

B. Heuristik B $(0,50093.101,41903) \rightarrow C(0,51732.101,41964)$

$\mathrm{H}(\mathrm{a}, \mathrm{b})=(0,51732-0,50093)+(101,41964-101,41903)$

$\mathrm{H}(\mathrm{a}, \mathrm{b})=(0,01639+0,00061) \quad=0,01699$

Hasil di ubah dalam derajat. $\quad=0,97$

C. Heuristik B $(0,50093$. 101,41903) $\rightarrow \mathrm{D}(0,51046.101,44916)$

$\mathrm{H}(\mathrm{a}, \mathrm{b})=(0,51046-0,50093)+(101,44916-101,41903)$

$\mathrm{H}(\mathrm{a}, \mathrm{b})=(0,00953+0,03013) \quad=0,03966$

Hasil di ubah dalam derajat. $\quad=2,27$

D. Heuristik C $(0,51732$. 101,41964) $\rightarrow \mathrm{E}(0,52692.101,43358)$

$\mathrm{H}(\mathrm{a}, \mathrm{b})=(0,52692-0,51732)+(101,43358-101,41964)$

$\mathrm{H}(\mathrm{a}, \mathrm{b})=(0,0096+0,51732) \quad=0,02354$

Hasil di ubah dalam derajat. $\quad=1,34$

E. Heuristik C $(0,51732$. 101,41964) $\rightarrow \mathrm{G}(0,53507.101,42019)$ 
$\begin{array}{ll}\mathrm{H}(\mathrm{a}, \mathrm{b})=(0,53507-0,51732)+(101,42019-101,41964) \\ \mathrm{H}(\mathrm{a}, \mathrm{b})=(0,01775+0,00055) & =0,0183 \\ \text { Hasil di ubah dalam derajat. } & =1,04\end{array}$

F. Heuristik D $(0,51046$. 101,44916) $\rightarrow \mathrm{E}(0,52692.101,43358)$

$\mathrm{H}(\mathrm{a}, \mathrm{b})=(0,52692-0,51046)+(101,43358-101,44916)$

$\mathrm{H}(\mathrm{a}, \mathrm{b})=(0,01646+0,01558) \quad=0,03204$

Hasil di ubah dalam derajat. $\quad=0,18$

G. Heuristik D $(0,51046$. 101,44916) $\rightarrow$ F $(0,53601.101,44744)$

$\mathrm{H}(\mathrm{a}, \mathrm{b})=(0,53601-0,51046)+(101,44744-101,44916)$

$\mathrm{H}(\mathrm{a}, \mathrm{b})=(0,01646+0,00172) \quad=0,01818$

Hasil di ubah dalam derajat. $\quad=1,04$

H. Heuristik E $(0,52692$. 101,43358) $\rightarrow \mathrm{H}(0,53530.101,43649)$

$H(a, b)=(0,53530-0,52692)+(101,43649-101,43358)$

$\mathrm{H}(\mathrm{a}, \mathrm{b})=(0,00838+0,00291) \quad=0,01129$

Hasil di ubah dalam derajat. $\quad=0,64$

I. Heuristik H $(0,53530$. 101,43649) $\rightarrow \mathrm{I}(0,53593.101,44311)$

$\mathrm{H}(\mathrm{a}, \mathrm{b})=(0,53593-0,53530)+(101,44311-101,43649)$

$\mathrm{H}(\mathrm{a}, \mathrm{b})=(0,00063+0,00662) \quad=0,00683$

Hasil di ubah dalam derajat. $\quad=0,39$

J. Heuristik G $(0,53507$. 101,42019) $\rightarrow \mathrm{H}(0,53530.101,43649)$

$\mathrm{H}(\mathrm{a}, \mathrm{b})=(0,53530-0,53507)+(101,43649-101,42019)$

$\mathrm{H}(\mathrm{a}, \mathrm{b})=(0,00023+0,00162) \quad=0,01653$

Hasil di ubah dalam derajat. $\quad=0,94$

K. Heuristik F $(0,53601$. 101,44744) $\rightarrow I(0,53593.101,44311)$

$\mathrm{H}(\mathrm{a}, \mathrm{b})=(0,53593-0,53601)+(101,44311-101,44744)$

$\mathrm{H}(\mathrm{a}, \mathrm{b})=(-0,00008+0,00433) \quad=0,00441$

Hasil di ubah dalam derajat. $\quad=0,25$

L. Heuristik I $(0,53593.101,44311) \rightarrow \mathrm{J}(0,53806$.101,44358)

$\mathrm{H}(\mathrm{a}, \mathrm{b})=(0,53806-0,53593)+(101,44358-101,44311)$

$\mathrm{H}(\mathrm{a}, \mathrm{b})=(-0,00213+0,00047) \quad=0,0026$

Hasil di ubah dalam derajat. $\quad=0,14$

Pada tabel dapat dilihat hasil dari perhitungan antara dua titik koordinat yang merupakan nilai perkiraan atau estimasi untuk nilai $h(n)$.

Tabel 2. Relasi kedua titik

\begin{tabular}{|c|c|c|}
\hline Titik_asal & Titik_tujuan & h(n) \\
\hline A & B & 0,24 \\
\hline B & C & 0,97 \\
\hline B & D & 2,27 \\
\hline C & G & 1,04 \\
\hline C & E & 1,34 \\
\hline D & E & 0.18 \\
\hline D & F & 1,04 \\
\hline E & H & 0,64 \\
\hline F & I & 0,25 \\
\hline G & H & 0,94 \\
\hline H & I & 0,39 \\
\hline I & J & 0,14 \\
\hline
\end{tabular}


Tabel 3 Jarak kedua titik

\begin{tabular}{|l|l|c|}
\hline Titik_asal & Titik_tujuan & $\begin{array}{c}\text { Jarakg(n) di } \\
\text { asumsikan ke } \\
\text { Km }\end{array}$ \\
\hline A & B & 1 \\
\hline B & C & 2 \\
\hline B & D & 5 \\
\hline C & G & 2 \\
\hline G & H & 1 \\
\hline C & E & 3 \\
\hline D & F & 4 \\
\hline D & E & 3 \\
\hline E & H & 2 \\
\hline H & I & 1 \\
\hline F & I & 1 \\
\hline I & J & 1 \\
\hline
\end{tabular}

Pada tabel 3 dapat kita lihat jarak antara dua titik koordinat dimana nilai jarak tersebut diasumsikan kedalam g(n). Setelah mendapatkan nilai heuristik dari proses di atas, selanjutnya adalah proses perhitungan jarak terpendek menggunakan Algoritma $A^{*}$ dilakukan dengan menggunakan rumus : $\mathrm{f}=\mathrm{g}+\mathrm{h}$, dimana :

$\mathrm{g}=$ jarak

$\mathrm{h}=$ heuristic

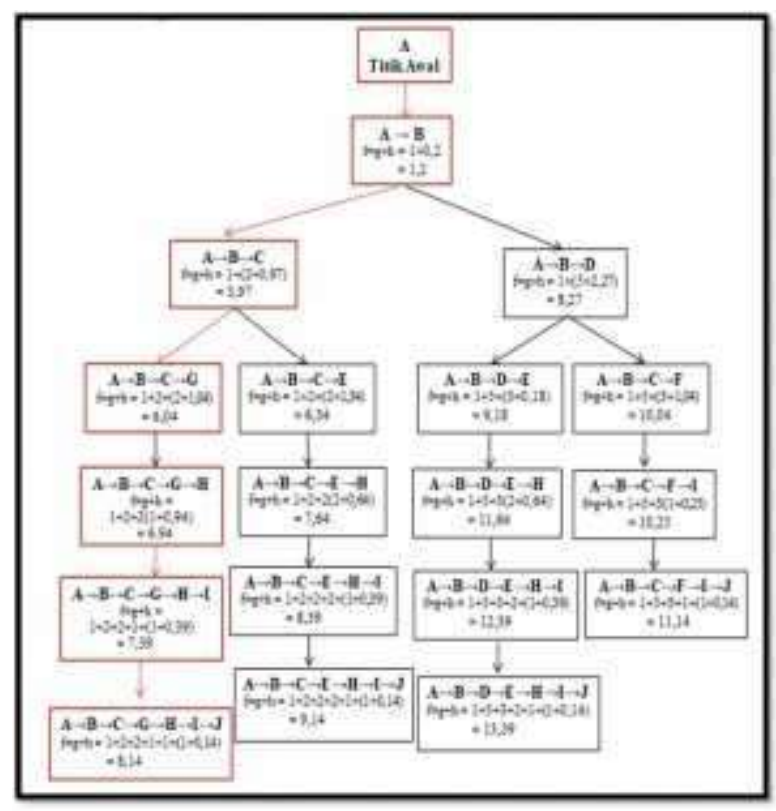

Gambar 2. Perhitungan jarak

Dari perhitungan di atas, nilai terendah yang didapatkan melalui perhitungan Algoritma (A*) dari titik asal (initial state) A menuju titik tujuan (goal state) J adalah melalui rute A-B-C-G-H-I-J yaitu 8.14 dan dapat disimpulkan bahwa jarak terdekat dari titik A ke titik J dengan Algoritma A* adalah melalui A-B-C-G-H-I-J dengan A-B = $1 \mathrm{~km}, \mathrm{~B}-\mathrm{C}=2 \mathrm{~km}, \mathrm{C}-\mathrm{G}=2 \mathrm{~km}, \mathrm{G}-\mathrm{H}$ $=1 \mathrm{~km}, \mathrm{H}-\mathrm{I}=1 \mathrm{~km}, \mathrm{I}-\mathrm{J}=1 \mathrm{~km}$ Maka total jarak yang ditempuh adalah 8 kilometer.

\section{Hasil dan Pembahasan}

Analisa kebutuhan sistem adalah sebagai spesifikasi perangkat yang di persiapkan dalam pembuatan sistem. bagaimana sistem harusnya bekerja atau bagian-bagian yang ada didalam sistem, yang digunakan dalam merancang sistem agar sistem dapat berjalan sesuai dengan yang di harapakan. 
Tabel. 4 Kebutuhan sistem

\subsection{Pengujian Sistem}

\begin{tabular}{|c|l|l|}
\hline Perangkat & \multicolumn{1}{|c|}{$\begin{array}{c}\text { Jenis } \\
\text { Perangkat }\end{array}$} & \multicolumn{1}{|c|}{ Sfesifikasi } \\
\hline \multirow{4}{*}{$\begin{array}{c}\text { Perangkat } \\
\text { Keras }\end{array}$} & Prosesor & $\begin{array}{l}\text { Intel(R) Core(TM) } \\
\text { i3-2120 CPU } \\
3.30 \mathrm{GHz}\end{array}$ \\
\cline { 2 - 3 } & & DDR 3. 4 GB \\
\cline { 2 - 3 } & Hardisk & 500 GB \\
\cline { 2 - 3 } & Sistem & Windows 7 Ultimate \\
& Operasi & \\
\cline { 2 - 3 } & Membuat & PHP \\
& program & \\
\cline { 2 - 3 } \begin{tabular}{c} 
Lerangkat \\
\cline { 2 - 3 }
\end{tabular} & Kerangka & Code Ingniter \\
\cline { 2 - 3 } & Kerja & \\
\cline { 2 - 3 } & Editor & Visual Studio Code \\
\hline
\end{tabular}

Pengujian sistem untuk mengetahui apakah system dapat berjalan dengan baik atau terdapat masalah dalam pengujian sistem yang telah di buat. Pengujian ini akan di lakukan di 5 titik di kecamatan yang berbeda untuk mengetahui apakah sistem yang di harapkan dapat berjalan sesuai yang di harapkan.

1) Pengujian Titik Kecamatan Bukit Raya

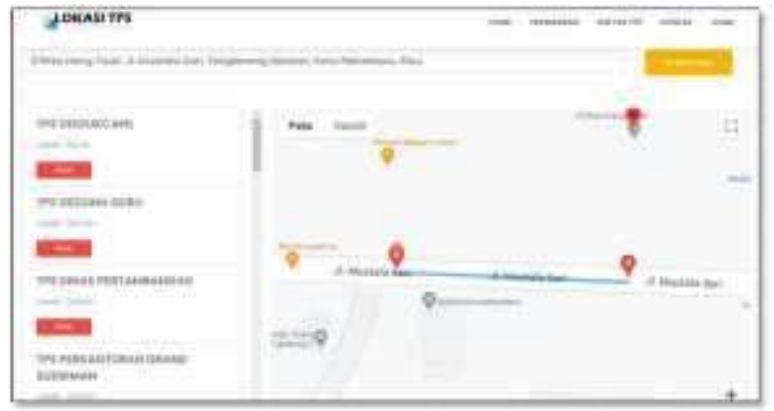

Gambar. 1 Pengujian titik kecamatan bukit raya

Pada gambar 3.1 terlihat hasil pengujian rute dari titik awal A berada di (STIKes Hang Tuah, Jl.Mustafa Sari, Tengkerang Selatan, Kota Pekanbaru, Riau) menuju titik B (Tps Disdukcapil Jl.Mustafa Sari, Tangkerang Selatan, Kec.Bukit Raya, Kota Pekanbaru, Riau) yang menunjukkan rute pada sistem.

2) Pengujian Titik Kecamatan Sukajadi

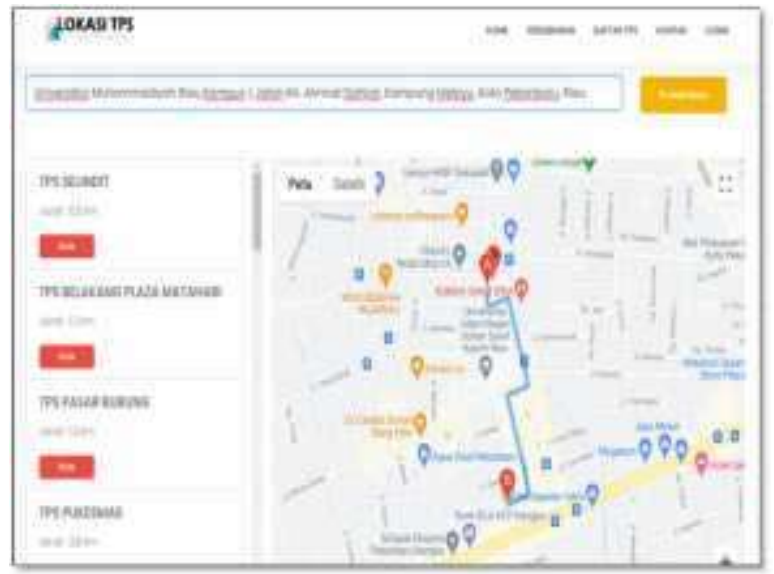

Gambar. 2 Pengujian titik kecamatan Sukajadi 
Pada gambar 2 terlihat hasil pengujian rute dari titik awal A berada di (Universitas Muhammadiyah Riau Kampus 1, Jl.KH. Ahmad Dahlan, Kota Pekanbaru, Riau) menuju titik B (Tps Selindit, Jl.Selindit Kec.Sukajadi, Kota Pekanbaru, Riau) yang menunjukkan rute pada sistem.

3) Pengujian titik Kecamatan Marpoyan Damai

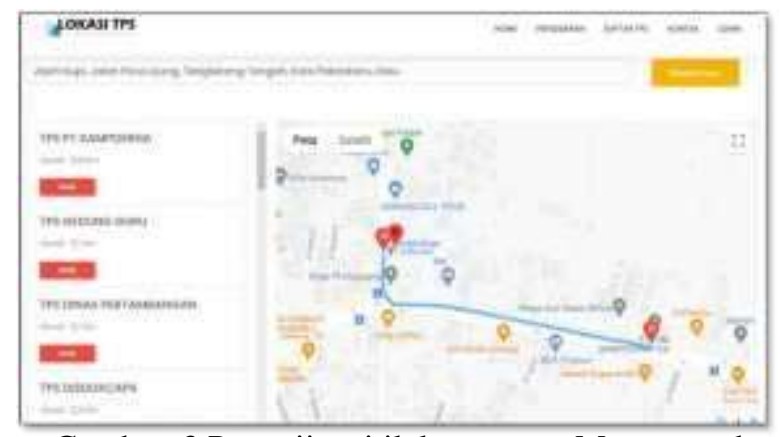

Gambar. 3 Pengujian titik kecamatan Marpoyan damai

Pada gambar 3 terlihat hasil rute pengujian dari titik awal A berada di (Atjeh Kupi, Jalan Paus Ujung, Tengkerang Tengah, Kota Pekanbaru, Riau) menuju titik B (Tps PT.Sampurna, Jalan Arifin Ahmad, Kecamatan Marpoyan Damai, Kota Pekanbaru, Riau) yang menunjukkan rute pada sistem.

4) Pengujian titik kecamatan lima puluh

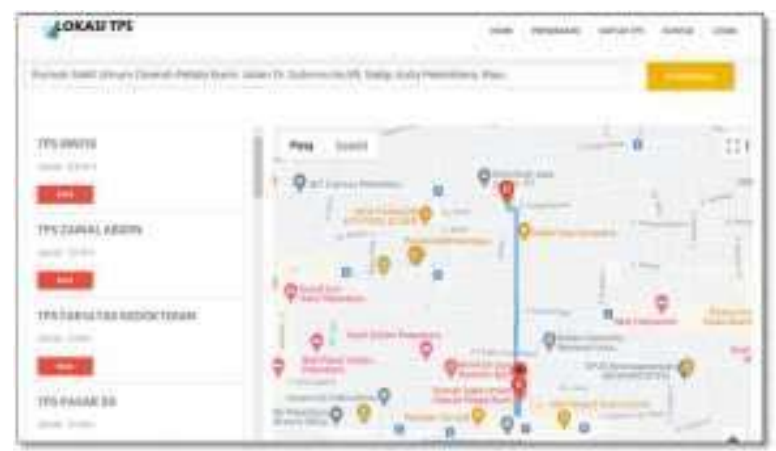

Gambar. 4 Pengujian titik kecamatan Marpoyan damai

Pada gambar 4 terlihat hasil pengujian rute dari titik awal A berada di (Rumah Sakit Umum Daerah Petala Bumi, Jalan Dr. Sutomo, Kecamatan Lima Puluh, Kota Pekanbaru, Riau) menuju titik B (Tps Rintis, Jl. Jalan Dr. Sutomo, Kecamatan Lima Puluh, Kota Pekanbaru, Riau) yang menunjukkan rute pada sistem.

5) Pengujian titik kecamatan rumbai pesisir

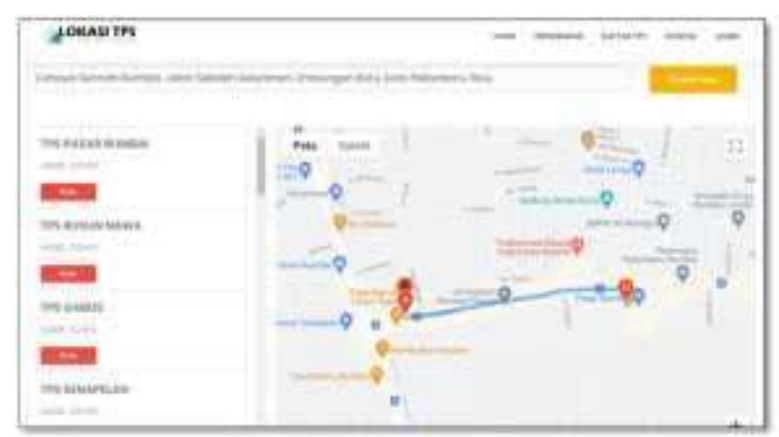

Gambar. 5 Pengujian titik kecamatan Marpoyan damai

Pada gambar 5 terlihat hasil rute pengujian dari titik awal A berada di (Cahaya Sunnah Rumbai, Jalan Sekolah, Kelurahan Limbungan Baru, Kecamatan Rumbai Pesisir, Kota Pekanbaru, Riau) menuju titik B (Tps Pasar Rumbai, Jalan Sekolah, Kelurahan Limbungan Baru, Kecamatan Rumbai Pesisir, Kota Pekanbaru, Riau) yang menunjukkan rute pada sistem.

\subsection{Hasil Pengujian}

Dari pengujian yang di lakukan, bertujuan untuk mengetahui apakah sistem dapat menampilkan titik tps terdekat dan sistem dapat berjalan menunjukkan rute terdekat dengan menggunakan algoritma $A^{*}$ menuju titik tujuan. Dari pengujian 
yang di lakukan di 5 daerah kecamatan yang ada di Kota Pekanbaru,sistem dapat berjalan dengan baik seperti terlihat pada tabel di bawah :

Tabel. 5 Hasil pengujian sistem

\begin{tabular}{|c|c|c|c|}
\hline No & Titik Awal & Titik Tujuan & Hasil \\
\hline 1. & $\begin{array}{l}\text { STIKes Hang Tuah, Jl.Mustafa Sari, } \\
\text { Tengkerang Selatan, Kota Pekanbaru, } \\
\text { Riau }\end{array}$ & $\begin{array}{lrr}\text { Tps } \quad \text { Disdukcapil } & \text { Jl.Mustafa } & \text { Sari, } \\
\text { Tangkerang Selatan, } & \text { Kec.Bukit Raya, } \\
\text { Pekanbaru, Riau }\end{array}$ & $\begin{array}{l}\text { Sistem Menunjukka } \mathrm{n} \text { rute terdekat } \\
\text { dari titik A ke titik B dengan jarak } \\
50 \mathrm{Mtr} \text {. }\end{array}$ \\
\hline 2. & $\begin{array}{l}\text { Universitas Muhammadi yah Riau } \\
\text { Kampus 1, Jl.KH. Ahmad Dahlan, Kota } \\
\text { Pekanbaru, Riau }\end{array}$ & $\begin{array}{l}\text { Tps Selindit, Jl.Selindit Kec.Sukajadi, } \\
\text { Kota Pekanbaru, Riau }\end{array}$ & $\begin{array}{l}\text { Sistem Menunjukka } \mathrm{n} \text { rute terdekat } \\
\text { dari titik A ke titik B dengan jarak } \\
0,8 \mathrm{Km} \text {. }\end{array}$ \\
\hline 3. & $\begin{array}{l}\text { Atjeh Kupi, Jalan Paus Ujung, } \\
\text { Tengkerang Tengah, Kota Pekanbaru, } \\
\text { Riau }\end{array}$ & $\begin{array}{l}\text { Tps PT.Sampurna, Jalan } \\
\text { Kecamatan Marpoyan Ahmad, } \\
\text { Pekanbaru, Riau }\end{array}$ & $\begin{array}{l}\text { Sistem Menunjukka } \mathrm{n} \text { rute terdekat } \\
\text { dari titik A ke titik B dengan jarak } \\
0,6 \mathrm{Km} \text {. }\end{array}$ \\
\hline 4. & $\begin{array}{l}\text { Rumah Sakit Umum Daerah Petala } \\
\text { Bumi, Jalan Dr. Sutomo, Kecamatan } \\
\text { Lima Puluh, Kota Pekanbaru, Riau }\end{array}$ & $\begin{array}{l}\text { Tps Rintis, Jl. Jalan Dr. Sutomo, } \\
\text { Kecamatan Lima Puluh, Kota Pekanbaru, } \\
\text { Riau }\end{array}$ & $\begin{array}{l}\text { Sistem Menunjukka } \mathrm{n} \text { rute terdekat } \\
\text { dari titik A ke titik B dengan jarak } \\
0,8 \mathrm{Km} \text {. }\end{array}$ \\
\hline 5. & $\begin{array}{l}\text { Cahaya Sunnah Rumbai, Jalan Sekolah, } \\
\text { Kelurahan Limbungan } \\
\text { Kecamatan Rumbai } \\
\begin{array}{l}\text { Pekanbaru, Riau } \\
\text { Pekisir, }\end{array} \\
\end{array}$ & $\begin{array}{l}\text { Tps Pasar Rumbai, Jalan Sekolah, } \\
\text { Kelurahan Limbungan Baru, Kecamatan } \\
\text { Rumbai Pesisir, Kota Pekanbaru, Riau }\end{array}$ & $\begin{array}{l}\text { Sistem Menunjukka } \mathrm{n} \text { rute terdekat } \\
\text { dari titik A ke titik B dengan jarak } \\
0,9 \mathrm{Km} \text {. }\end{array}$ \\
\hline
\end{tabular}

\section{KESIMPULAN}

Berdasarkan analisis dari sistem dan pengujian sistem secara menyeluruh yang telah dilakukan pada bab sebelumnya, maka ada beberapa hal yang dapat dijadikan kesimpulan pada penelitian ini antara lain:

1. Algoritma A* (A Star) dengan modifikasi mampu menyelesaikan permasalahan dalam menentukan jarak terpendek.

2. Sistem penentuan jalur terpendek dengan menggunakan algoritma $A *$ (A Star) juga mampu menentukan jalur tersingkat dengan perhentian yang ditetapkan.

\section{DAFTAR PUStaka}

[1] Abdichianto, Cleoputra. G., (2020). "Pengembangan Aplikasi Tempat Sampah Pintar Berbasis Website Dan Mobile." Jurnal Ilmu Komputer. 1-79

[2] Elmayati, C. W., and Hendara Saputra. (2018). "Perancangan Sistem Informasi Geografis Pemetaan Lokasi Pembuangan Sampah Legal Pada Dinas Kebersihan Dan Pertamanan Kota Lubuklinggau Berbasis Web Mobile”. Jurnal TAM (Technology Acceptance Model) 9:106-113

[3] Kurniawan, O. R., Meyka N. A., And Pradityo Utomo. (2019). “Aplikasi Pemetaan Lokasi Tpa Kota Madiun Berbasis Android Dengan Bantuan SIG (Sistem Informasi Geografis).” 1918-1924.

[4] Purnama, S., Megawaty, D. A., dan Fernando, Yusra (2018). Penerapan Algoritma A Star Untuk Penentuan Jarak Terdekat Wisata Kuliner di Kota Bandarlampung.Jurnal Teknoinfo, 12(1),

[5] Prasetyo, A. C., Arnandi, M. P., Hudnanto, H. S., and Setiaji, Bayu. (2017). Perbandingan Algoritma Astar dan Dijkistra Dalam Menentukan Rute Terdekat Astar and Dijkistra Algorithm Comparison for Determining the Shortest Route. 36-

[6] Tedy, Setiadi. (2018). "Perancangan Sistem Informasi Geografis Pemetaan Daerah Rawan Tanah Longsor.” Jurnal Algoritma 7(1):1-54.

[7] Umar, R., Yuhhana, A., dan Prayudi Andi (2019). Analisis Perbandingan Algoritma Djikstra, A-Star, Dan Floyd Warshall Dalam Pencarian Rute Terdekat Pada Objek Wisata Kabupaten Dompu. 8(2), 227-234.

[8] Wulandari, Eka. (2018). "Sistem Informasi Geografis Pemetaan Titik Lokasi Pembuangan Sampah Kota Pekanbaru." Skripsi. Program Sistem Informasi Universitas Islam Negeri Sultan Syarif Kasim Riau.

[9] Wicaksono, W., Rahayu, Suryaningtyas, Sugiarto, Edi, Luthfiarta, Ardytha, and Nuswantoro, Universitas Dian. (2019). Pencarian Rute Terdekat Sanggar Tari Menggunakan Algoridma Floyd Wharsall Di Wilayah Solo Dan Semarang. 24(2), 69-81.

[10] Wardani, Rafqi Fuad, E. (2019). Implementasi Floyd Warshall dalam Menentukan Rute Terpendek Menuju Halte Trans Metro Pekanbaru. 1(1).

[11] Zaki Fadhly, M., Fuad, E., \& Soni. (2019). Perancangan Sistem Informasi Geografis Wisata Sejarah Dan Budaya Di Kota Pekanbaru Menggunakan Location Based Service(LBS). Prosiding Seminar Nasional Computation Technology and Its Aplication, 1(1), 35-40. 